Белоусов Владимир Николаевич

старший преподаватель

кафедры гражданского права и процесса

Байкальского государственного университета

\section{СОЗДАНИЕ АНТИСОЦИАЛЬНОГО ПРОИЗВЕДЕНИЯ ПО ДОГОВОРУ АВТОРСКОГО ЗАКАЗА}

\section{Аннотация:}

В статье представлены признаки антисоциальных произведений. Обоснован вывод, что при создании такого произведения договор авторского заказа следует признавать недействительным. Определены последствия признания договора недействительным. Доказана необходимость закрепления в гражданском законодательстве односторонней реституции на случай признания сделки недействительной. Установлено, что гражданско-правовую ответственность за антисоциальное произведение перед иными лицами должен нести непосредственно творец, т. е. автор, поскольку его «творческим» трудом создано подобное произведение. Следует говорить об индивидуальной ответственности. Аналогичный вывод об индивидуальной гражданской ответственности автора можно сделать и при распространении асоциального произведения как автором, так и заказчиком. Кроме гражданской ответственности, создание антисоциального произведения влечет ответственность, предусмотренную нормами публичного права.

Ключевые слова:

договор авторского заказа, заказчик, автор, предмет договора, произведение, ответственность, недействительные сделки, правопорядок, нравственность, реституция.

\section{Belousov Vladimir Nikolaevich}

Senior Lecturer, Department of Civil Law and Procedure, Baikal State University

\section{THE CREATION OF ANTISOCIAL WORKS UNDER THE AUTHOR'S ORDER AGREEMENT}

The study presents the characteristics of anti-social works. The author proves that in case of creation of an antisocial work the author's order agreement should be recognized invalid. The consequences of invalidation of the agreement are determined. The research substantiates that it is necessary to enshrine the unilateral restitution in civil legislation if the transaction is invalid. In the author's opinion, the civil liability for antisocial work with respect to other persons should be directly borne by the creator, i.e. the author, because he created such a work. The individual responsibility should be discussed in this regard. A similar conclusion about the individual civil liability of the author can be made if both the author and the customer distribute the antisocial work. In addition to the civil liability of the author, the creation of an antisocial work entails liability under the public law.

Keywords: author's order agreement, customer, author, subject matter of an agreement, work, responsibility, invalid transactions, rule of law, morality, restitution.

В соответствии со ст. 1288 Гражданского кодекса РФ (далее - ГК РФ) по договору авторского заказа автор обязуется по заказу заказчика создать обусловленное договором произведение на материальном носителе или в иной форме [1]. Из легального определения анализируемого договора следует, что предмет договора авторского заказа - это создание произведения, соответствующее соглашению сторон. Оно должно быть создано творческим трудом, обладать новизной, оригинальностью, иметь объективную форму выражения.

Интерес представляет ситуация, в которой автор обязуется в соответствии с договором авторского заказа создать произведение, которое противоречит нормам морали и нравственности, основам правопорядка, государственной идеологии, религиозной доктрине. Такие произведения предложено называть асоциальными (антисоциальными). В зарубежной юридической литературе справедливо отмечается, что мировому сообществу срочно нужны четкие и ясные правила, определяющие надлежащие объекты авторских прав, отражающие сопутствующие механизмы их создания, передачи, использования, изменения и уничтожения [2, р. 220].

Вместе с тем степень научной разработанности темы исследования нельзя признать соответствующей уровню ее теоретической и практической актуальности. Отсутствуют диссертационные работы, научные статьи, монографии, посвященные созданию антисоциального произведения по договору авторского заказа. Не определены последствия их создания. Остаются дискуссионными способы защиты субъектов гражданского права в случае создания подобных объектов авторского права. Все изложенное свидетельствует о востребованности юридической наукой и практикой целостного исследования создания антисоциального произведения по договору авторского заказа, что и обусловило выбор темы настоящей статьи.

В доктрине называются лишь некоторые признаки антисоциального произведения: 1) может быть квалифицировано как злоупотребление правом на свободу творчества; 2) создание такого объекта авторского права подпадает под действие административной или уголовной ответственности; 3) конфликтует с этическими нормами, противоречит публично-правовым запретам [3, с. 20]. 
В толковом словаре под редакцией С.И. Ожегова, Н.Ю. Шведовой нравственность определяется как внутренние, духовные качества, которыми человек руководствуется, этические нормы, правила поведения, определяемые этими качествами. В юридической литературе под основами нравственности предложено понимать принятые в обществе представления о моральных устоях, т. е. очевидных нравственных принципах и нормах надлежащего поведения [4, с. 29]. Требования нравственности в отличие от права не закреплены в системе писаных норм [5, с. 38]. Для каждого отдельного общества, государства характерна своя трактовка нравственности [6, с. 20]. Однако в любом случае к безнравственным следует отнести, например, договор авторского заказа порнографического издания. Под основами правопорядка понимаются основополагающие нормы о социально-экономическом устройстве общества, следствием несоблюдения которых может быть нарушение социальной стабильности, территориальной целостности государства, его суверенитета [7, с. 47]. Е.А. Суханов отмечает, что категория «основы правопорядка» по содержанию синонимична понятию публичного порядка, используемому в международном частном праве [8].

В доктрине гражданского права, в частности в работе Е.А. Гнатко [9], и законодательстве условиями действительности сделок традиционно признают следующие составляющие: 1) законность содержания (соответствие требованиям закона); 2) способность ее субъектов к участию в сделке (обладание дееспособностью); 3) соответствие воли и волеизъявления; 4) соблюдение формы сделки. В качестве сделок, совершенных с целью, противной основам правопорядка или нравственности, могут быть квалифицированы сделки, которые нарушают основополагающие начала российского правопорядка, принципы общественной, политической и экономической организации общества, его нравственные устои. К таковым могут быть отнесены, например, сделки, направленные на изготовление, распространение литературы и иной продукции, пропагандирующей войну, национальную, расовую или религиозную вражду. Ввиду нарушения условия о законности содержания сделки при создании асоциального произведения договор авторского заказа является недействительным в силу ст. 169 ГК РФ: недействительность сделки, совершенной с целью, противной основам правопорядка или нравственности [10].

В соответствии с определением Конституционного суда РФ № 226-О квалифицирующим признаком антисоциальной сделки является ее цель, т. е. достижение такого результата, который не просто не отвечает закону или нормам морали, а противоречит - заведомо и очевидно для участников гражданского оборота - основам правопорядка и нравственности [11]. Следовательно, правовой результат, к достижению которого стремится хотя бы один из контрагентов, должен очевидным образом противоречить нравственности или основам правопорядка (при наличии умысла), а не просто не соответствовать нормам морали или закону. Думается, что создание антисоциального произведения по договору авторского заказа невозможно без умысла автора. Иначе нужно ставить вопрос о недееспособности автора.

В ст. 169 ГК РФ не содержится норм относительно лиц, которые имеют право требовать применения последствий недействительности антисоциальной сделки. В связи с этим в случае признания договора авторского заказа на создание асоциального произведения недействительным необходимо руководствоваться ст. 166 ГК РФ.

Создание асоциального произведения по договору авторского заказа влечет недействительность договора, наступают следующие последствия. При наличии умысла у автора и заказчика - в случае исполнения договора обеими сторонами - в доход государства взыскивается все полученное ими по договору, а при исполнении договора одной стороной с другой стороны взыскивается в доход государства все полученное ею и все причитавшееся с нее первой стороне в возмещение полученного. При наличии умысла лишь у одной из сторон такого договора все полученное ею по договору должно быть возвращено другой стороне, а полученное последней либо причитавшееся ей в возмещение исполненного взыскивается в доход государства. Таким образом, в настоящее время в гражданском законодательстве не предусмотрено правил об односторонней реституции на случай признания сделок недействительными. С таким подходом вряд ли можно согласиться. Думается, что целесообразно сохранение односторонней реституции для договора авторского заказа. Это способствовало бы дифференциации последствий создания асоциального произведения, поскольку в первоначальное положение восстанавливался бы только заказчик. Автора как создателя асоциального произведения в первоначальное положение восстанавливать не следует. Поэтому в ГК РФ нужно вернуть правила об односторонней реституции.

Помимо признания договора авторского заказа на создание асоциального произведения недействительным может возникнуть следующий вопрос: кто несет гражданско-правовую ответственность за создание антисоциального произведения перед иными лицами - автор, т. е. лицо, его непосредственно создавшее, или заказчик - лицо, по заданию которого было создано асоциальное произведение? Отметим, что иное лицо может заявить свои требования в случае, если такое произведение нарушает его охраняемый законом интерес. Это может иметь место и в том 
случае, когда требования возникают из создания произведения, направленного, например, на героизацию Бандеры и Шухевича. Тогда требования заявляются лицами, пострадавшими от деятельности указанных личностей. При этом иные лица правомочны использовать способы защиты, закрепленные в ст. 12 ГК РФ, в первую очередь речь идет о компенсации морального вреда. Не исключается возможность для применения мер ответственности, предусмотренных в отношении внедоговорных обязательств. Так, в ст. 1064 ГК РФ устанавливается, что вред, причиненный личности, подлежит возмещению в полном объеме лицом, причинившим вред.

Разумеется, на предложение заказчика о создании подобного рода произведения автор должен ответить отказом, поскольку такое произведение является антисоциальным, что неизбежно повлечет наступление неблагоприятных последствий. Перед созданием произведения автор должен убедиться, что оно не будет подрывать основы правопорядка, выходить за рамки морали и нравственности. В том случае, если автор не откажется, следует говорить об индивидуальной ответственности. Полагаем, что гражданско-правовую ответственность за антисоциальное произведение перед третьими лицами должен нести непосредственно творец, т. е. автор, поскольку его «творческим» трудом оно создано. Аналогичный вывод об индивидуальной гражданской ответственности автора можно сделать и при распространении асоциального произведения как автором, так и заказчиком, поскольку именно автор является его создателем. Более того, создание антисоциального произведения не соответствует принципу разумности. Как справедливо отмечает Ю.В. Виниченко, «действовать разумно - значит действовать сообразно гражданскому обороту» [12, с. 59].

Кроме гражданской ответственности автора, создание антисоциального произведения влечет ответственность, предусмотренную нормами публичного права. Например, в ст. 242.1 Уголовного кодекса РФ прописана уголовная ответственность за изготовление и оборот материалов или предметов с порнографическими изображениями несовершеннолетних. В этой ситуации за создание (а также распространение) антисоциального произведения автор может привлекаться как к гражданской ответственности, так и к уголовной. Если заказчик распространяет подобные произведения, то он привлекается только к уголовной ответственности. Возложение уголовной ответственности на заказчика объясняется состоявшейся передачей ему объекта авторского права. Следует поддержать вывод Т.В. Ламм и Е.В. Титова, что передача вещи устанавливает «фактическое господство» лица, которому вещь передана, с этого момента приобретатель получает абсолютную позицию против всех третьих лиц [13, с. 551].

Таким образом, в случае создания автором антисоциального произведения договор авторского заказа следует признавать ничтожным по правилам ст. 169 ГК РФ. Кроме того, на автора за создание и распространение асоциального произедения возлагаются дополнительные меры ответственности, предусмотренные нормами гражданского и уголовного права.

\section{Ссылки:}

1. Гражданский кодекс РФ : федер. закон от 18 дек. 2006 г. № 230-Ф3. Ч. 4 // Собрание законодательства РФ. 2006. № 52, ч. 1. Ст. 5496.

2. Ritter J., Mayer A. Regulating data as property: a new construct for moving forward // Duke Law \& Technology Review. 2018. No. 1. P. 220-277.

3. Братусь Д.А. Антисоциальные произведения // Вопросы юридической юстиции. 2015. № 2, ч. 2. С. 19-23.

4. Данилов И.А. Ничтожность сделки, противоречащей основам нравственности // Гражданское право. 2013. № 6. С. 28-30.

5. Свит Ю.П. Проблемы правовой квалификации антисоциальных сделок // Цивилист. 2007. № 4. С. 38-41.

6. Гусенкова Ю.А. Сущность основ правопорядка и нравственности при квалификации сделки по статье 169 ГК РФ // Юрист. 2013. № 10. С. 19-22.

7. Егоров Ю.П. Недействительность противозаконных по содержанию сделок // Законность. 2004. № 6. С. 47-51.

8. Суханов Е.А. Антисоциальные сделки в науке и практике // Юрист. 2005. № 8. С. 1-4.

9. Гнатко Е.А. Недействительность исполнительных документов и основания признания их таковыми // Baikal Research Journal : электрон. науч. журн. 2016. Т. 7, № 6. https://doi.org/10.17150/2411-6262.2016.7(6).22.

10. О применении судами некоторых положений раздела І части первой Гражданского кодекса РФ [Электронный ресурс] : постановление Пленума Верховного суда РФ от 23 июня 2015 г. № 25. Доступ из справ.-правовой системы «КонсультантПлюс».

11. Об отказе в принятии к рассмотрению жалобы открытого акционерного общества «Уфимский нефтеперерабатывающий завод» на нарушение конституционных прав и свобод статьей 169 Гражданского кодекса РФ и абзацем третьим пункта 11 статьи 7 Закона РФ «О налоговых органах РФ» [Электронный ресурс] : определение Конституционного суда РФ от 8 июня 2004 г. № 226-О. Документ опубликован не был. Доступ из справ.-правовой системы «КонсультантПлюс».

12. Виниченко Ю.В. Отдельные аспекты проблемы разумности в гражданском обороте // Известия Байкальского государственного университета экономики и права. 2006. № 6. С. 58-62.

13. Ламм Т.В., Титов Е.В. Правовая природа передачи вещи как элемента фактического состава реального договора // Там же. 2017. Т. 27, № 4. С. 546-553. 


\section{References:}

Bratus, DA 2015, 'Antisocial works', Voprosy yuridicheskoy yustitsii, No. 2, part 2, pp. 19-23, (in Russian).

Danilov, IA 2013, 'The nullity of a transaction contradicting the ethical principles', Grazhdanskoye parvo, No. 6, pp. 28-30, (in Russian).

Egorov, YuP 2004, 'The invalid illegal transactions', Zakonnost', No. 6, pp. 47-51, (in Russian).

Gnatko, EA 2016, 'Invalidity of executive documents and grounds of recognizing them as such, Baikal Research Journal, vol. 7, No. 6, https://doi.org/10.17150/2411-6262.2016.7(6).22.

Gusenkova, YuA 2013, 'The essence of the law foundations and morality in the qualification of the transaction under the Article 169 of the Civil Code of the Russian Federation', Yurist, No. 10, pp. 19-22, (in Russian).

Lamm, TV \& Titov, EV 2017, 'The legal nature of the transfer of the property as an element of a set of facts of a tangible agreement', Izvestiya Baykal'skogo gosudarstvennogo universiteta ekonomiki i prava, vol. 27, No. 4, pp. 546-553, (in Russian).

Ritter, J \& Mayer, A 2018, 'Regulating data as property: a new construct for moving forward', Duke Law \& Technology Review, No. 1, pp. 220-277.

Svit, YuP 2007, 'Problems of legal qualification of antisocial transactions', Tsivilist, No. 4, pp. 38-41, (in Russian).

Sukhanov, EA 2005, 'Antisocial transactions in science and practice', Yurist, No. 8, pp. 1-4, (in Russian).

Vinichenko, YuV 2006, 'Some aspects of the intelligence problem in civil circulation', Izvestiya Baykal'skogo gosudarstvennogo universiteta ekonomiki i prava, No. 6, pp. 58-62, (in Russian). 